\title{
Populismens retorikk: trussel eller ressurs for deliberativt demokrati?
}

Å deliberere (eng: to deliberate) vil si å drøfte noe, for eksempel sannheten av en påstand eller riktigheten av en handling, ved å vurdere grunner for og imot. ${ }^{1}$ At en demokratiteori er «deliberativ», betyr som minimum at den tildeler offentlig politisk diskusjon en eller flere sentrale funksjoner i et velfungerende demokrati. ${ }^{2}$ Til forskjell fra «aggregative» modeller som fokuserer på stemmegiving og majoritetsstyre, ser deliberative modeller demokratiet som en løpende diskusjon mellom (ideelt sett) frie og likestilte borgere. Det er gjennom demokratisk deliberasjon at lovgiving og maktutøvelse får legitimitet, tvilsomme påstander utfordres, minoriteter blir hørt, dominans og urettferdighet kritiseres, med mer. Deliberative demokrater er derfor ikke bare opptatt av ytringsfrihet, men også av kvaliteten på det som sies og hvem som kommer til orde; av politiske, kulturelle og sosioøkonomiske betingelser for demokratisk deltagelse; samt av etiske og kognitive forutsetninger for vellykket deliberasjon. ${ }^{3}$

Dette impliserer ikke, slik noen kritikere hevder, en naiv tro på at komplekse samfunn kan styres via rasjonell argumentasjon alene, eller at deliberasjon kan løse alle konflikter og uenigheter. ${ }^{4}$ Politiske diskusjoner ender sjelden i enighet om hva som bør gjøres og hvem som bør gjøre det. Med jevne mellomrom må stemmene derfor telles opp slik at makt og ansvar kan fordeles, byråkratiet må fungere, og rettssystemet må dømme og straffe i henhold til gjeldende lover. Deliberativt

\footnotetext{
${ }^{1}$ Takk til Geir O. Rønning, Magnus Egan og Agoras anonyme fagfeller for kommentarer og forbedringsforslag.

${ }^{2}$ Innflytelsesrike verker i den deliberative tradisjonen inkluderer James S. Fishkin, Democracy and Deliberation. New Directions for Democratic Reform. New Haven, CT: Yale University Press 1991; James Bohman, Public Deliberation. Pluralism, Complexity, and Democracy. Cambridge, Mass.: The MIT Press 1996; Jürgen Habermas, Between Facts and Norms. Contributions to a Discourse Theory of Law and Democracy. Cambridge, Mass.: The MIT Press 1998; Jon Elster (red.), Deliberative Democracy. Cambridge: Cambridge University Press 1998; John Rawls, Political Liberalism. New York: Colombia University Press 2005.

${ }^{3}$ Simone Chambers, «Deliberative democratic Theory», i Annual Review of Political Science, 6, 2003, 203.

${ }^{4}$ Chantal Mouffe, «Deliberative Democracy or Agonistic Pluralism», i Political Science Studies, IHS Wien 72, 2000.
} 
demokrati kan med andre ord ikke fungere uten aggregative mekanismer, administrasjon og maktutøvelse. Poenget er altså ikke å erstatte disse mekanismene med deliberasjon, men at de i seg selv er mangelfulle. Avstemninger, for eksempel, er effektive i forhold til å vedta beslutninger eller velge representanter, men uten en forutgående prosess der alternative synspunkter har vært gjenstand for offentlig drøfting, mangler vi en form for kvalitetssikring, dvs. en mekanisme som motiverer stemmegiverne til å reflektere kritisk over egne preferanser og antakelser. ${ }^{5}$

Jeg drøfter i denne artikkelen hva populisme er, og hvorvidt populisme er en trussel eller ressurs for deliberativt demokrati. Jeg knytter an til den akademiske debatten om populisme ved å se på to innflytelsesrike populismedefinisjoner i moderne politisk teori: den agonistiske (Ernesto Laclau og Chantal Mouffe) og den ideologiske (Cas Mudde og Cristóbal Rovira Kaltwasser). Jeg anerkjenner det teoretiske bidraget $\mathrm{i}$ begge modeller og inkluderer sentrale elementer herfra i min egen posisjon. Samtidig viser jeg hvordan begge modeller byr på problemer som en deliberativ tilnærming bør unngå. Når det gjelder den agonistiske modellen, kritiserer jeg dens manglende kritiske distanse til det populistiske kravet om å snakke på vegne av «folket». Jeg er enig med Laclau og Mouffe $i$ at appellen til en konflikt mellom «folket» og «makthaverne» kan ha en rekke demokratiserende effekter, men peker samtidig på at hverken Laclau eller Mouffe er i stand til å skille mellom produktive og problematiske varianter av denne appellen.

Når det gjelder den ideologiske modellen, kritiserer jeg påstanden om at populisme er en ideologi som former populistens politiske virkelighetsforståelse. Vi vet av gode grunner ikke noe om hvorvidt populister selv tror på det de sier, og vi trenger heller ikke vite det. Det viktige, sett fra et deliberativt perspektv, er det som blir sagt og de konsekvenser det har for den offentlige samtalen. Jeg kritiserer også tendensen i den ideologiske modellen til å se populisme som en enten/eller-kategori, dvs. en kategori som politiske aktører enten tilhører eller ikke tilhører. Populisme, hevder jeg, kan med fordel sees som en graduell kategori som politiske aktører faller mer eller mindre inn under.

Gjennom diskusjonen med den agonistiske og den ideologiske modellen kommer jeg frem til at deliberative demokrater bør forstå populisme som en form for

\footnotetext{
${ }^{5}$ John Dryzeck definerer deliberasjon som «communication that induces reflection on preferences, values and interests in a non-coercive fashion» i Deliberative Democracy and Beyond. Liberals, Critics, Contestations. Oxford: Oxford University Press 2000, 76.
} 
politisk retorikk. Denne retorikken, som finnes i både høyre- og venstreorienterte varianter, kan enten være svak eller sterk, avhengig av dens logos (ideologiske innhold), ethos (talerens selvfremstilling) og pathos (følelsesmessige appell). Den sterke populismen er prinsipielt uforenlig med det deliberative demokratiidealet, og har en ødeleggende virkning på den demokratiske offentligheten. Den svake, derimot, er ikke uforenlig med det deliberative idealet som sådan. Likevel kan den ha en rekke forskjellige innvirkninger på demokratisk deliberasjon, både positive og negative.

\section{Deliberativt demokrati: inklusjon, opplysning, respekt}

Jeg kommer ikke i denne artikkelen til å gå inn på aktuelle diskusjoner internt i den deliberative teoritradisjonen, ${ }^{6}$ ei heller gå i dybden med den teoretiske fremstillingen av denne tradisjonen. Jeg fokuserer i stedet mer generelt på tre normative idealer som etter mitt syn uttrykker kjernen i den deliberative forståelsen av demokrati, nemlig inklusjon, opplysning, og respekt. Et velfungerende deliberativt demokrati, hevder jeg, orienterer seg mot disse idealene gjennom dets demokratiske funksjon (inklusjon), dets etiske funksjon (respekt) og dets epistemiske funksjon (opplysning). ${ }^{7}$

\section{Den demokratiske funksjonen: inklusjon}

Den mest grunnleggende normative intuisjonen i deliberativ demokratiteori er at legitim lovgiving springer ut av borgenes offentlige diskusjoner, både i den formelle offentligheten (parlamenter, ministerier, administrasjon osv.) og i den uformelle (ikke-statlige medier og fora). Det som først og fremst gir et politisk system demokratisk legitimitet, ifølge denne modellen, er at borgerne har tilnærmet lik mulighet for å ytre seg og påvirke politiske prosesser, enten på egen hånd eller via representanter. Dette er av Mansbridge m.fl. beskrevet som den «demokratiske funksjonen» $\mathrm{i}$ et deliberativt system. Målet er ikke konsensus, men inklusjonen av «multiple and plural voices, interests, concerns, and claims on the basis of feasible equality». ${ }^{8}$ Deliberative demokrater anerkjenner at lovforslag i siste instans er noe som folkevalgte politikere stemmer for eller mot, men de insisterer på at det som gjør

\footnotetext{
${ }^{6}$ For en oversikt, se Jürg Steiner, The Foundations of Deliberative Democracy. Empirical Research and Normative Implications. Cambridge: Cambridge University Press 2012.

${ }^{7}$ Min fremstilling av disse tre idealene er inspirert av Jane Mansbridge m.fl.: «A Systemic Approach to Deliberative Democracy», i Jane Mansbridge og John Parkinson, Deliberative Systems. Cambridge: Cambridge University Press 2012.

${ }^{8}$ Ibid., 12.
} 
slike majoritetsavgjørelser legitime, er de forutgående demokratiske prosessene der forskjellige grupper og synspunkter har blitt hørt, og minoriteter har fătt mulighet til å protestere.

Det er imidlertid enkelt å påvise at dette idealet ikke stemmer med virkeligheten: Demokratiske debatter er de facto er preget av en rekke ekskluderingsog marginaliseringsmekanismer, både i form av kulturelle stigma og statushierarkier (eksempelvis rasisme eller kjønnsprivilegier) og i form av økonomisk skeivfordeling (eksempelvis reproduksjonen av materiell deprivasjon i bestemte samfunnsgrupper). ${ }^{9}$ I tillegg er viktige politiske beslutninger overlatt til økonomiske dominansforhold i det «frie marked», og til udemokratiske ekspertorganer (for eksempel sentralbanker), og på den måten unndratt demokratisk kontroll. Marxistiske og poststrukturalistiske tenkere henviser gjerne til slike forhold når de argumenterer for at deliberative demokrater som Rawls og Habermas ikke forstår at det finnes makt, eller hvordan makt fungerer, i liberale demokratier. ${ }^{10}$ Denne kritikken er imidlertid lite overbevisende da verken Rawls eller Habermas påstår at slike fenomener ikke forekommer empirisk. Habermas har eksempelvis mye å si om sosial makt, marginalisering, og strukturell vold i liberale demokratier. ${ }^{11}$ Han knytter slike fenomener kausalt til feilslåtte nyliberale økonomier, på den ene siden, og til høyrepopulisme forstått som et protestfenomen, på den andre: «The Left in Europe must ask itself why right-wing populism is succeeding in winning over the oppressed and disadvantaged for the false path of national isolation.» ${ }^{12}$ Idealet om inkludering skal med andre ord forstås som et regulativt ideal (et ideal vi aldri kan realisere, men likevel bør orientere oss mot), og som må ledsages av kontinuerlige samfunnskritiske analyser av hvordan ekskludering og marginalisering faktisk foregår.

\footnotetext{
${ }^{9}$ Kulturell (mis)anerkjennelse og økonomisk skeivfordeling er ofte implisert i hverandre i sosiale praksiser, men fungerer likevel som analytisk distinkte kategorier. Se Nancy Frasers bidrag i Nancy Fraser og Axel Honneth, Redistribution or Recognition? A Political-Philosophical Exchange. London: Verso 2003.

${ }^{10}$ Jf. f.eks. Chantal Mouffe, Om det politiske. Oslo: Cappelen Damm akademisk 2015; Talal Asad, Formations of the Secular. Christianity, Islam, Modernity. Stanford: Stanford University Press 2003.

${ }^{11}$ Giovanna Borradori, «Fundamentalism and Terror: A Dialogue with Jürgen Habermas», i Giovanna Borradori, Philosophy in a Time of Terror. Dialogues with Jürgen Habermas and Jacques Derrida. Chicago: University of Chicago Press 2003, 35.

12 Jürgen Habermas, «For A Democratic Polarisation: How To Pull The Ground From Under Rightwing Populism». Intervju nedlastet 14.11.2019 på nettsiden: https://www.socialeurope.eu/democraticpolarisation-pull-ground-right-wing-populism.
} 


\section{Den epistemiske funksjonen: opplysning}

Høy grad av inklusjon i offentlige debatter sier imidlertid ikke i seg selv noe om kvaliteten på det som blir sagt. En politisk prosess som er preget av feilinformasjon, konspirasjonsteorier, uprøvde fordommer eller politisk propaganda, vil ifølge sakens natur ha lav epistemisk kvalitet, dvs. at sannsynligheten for at den resulterer i kloke og velbegrunnede beslutninger, er lav. En sentral del av den offentlige diskusjonens eksistensberettigelse er derfor dens «epistemiske funksjon»:

The epistemic function of a deliberative system is to produce preferences, opinions, and decisions that are appropriately informed by facts and logic and are the outcome of substantive and meaningful consideration of relevant reasons. A healthy deliberative system is one in which relevant considerations are brought forth from all corners, aired, discussed and appropriately weighed. ${ }^{13}$

I lys av dette idealet om opplysning kan vi skille mellom epistemiske og ikkeepistemiske deliberative demokrater, henholdsvis de som følger Jürgen Habermas i fremhevelsen av gjensidig læring og frigjøring gjennom deliberasjon, og de som følger John Rawls’ «unngåelsesmetode». ${ }^{14}$ Den rawlsianske posisjonen er basert på synet om at appeller til «sannhet» i politisk debatt er paternalistiske og polariserende, og at vi derfor bør innta en «agnostisk» posisjon til omfattende filosofiske, religiøse, moralske eller politiske uenigheter. ${ }^{15}$ Den habermasianske posisjonen, som jeg følger her, hevder derimot at kritisk drøfting av sannhetspostulater, ideologier og omfattende doktriner har en sentral plass i politisk debatt, og er avgjørende for utviklingen av reflekterte politiske holdninger. ${ }^{16}$ Den hevder videre at utviklingen av reflekterte politiske holdninger er viktig om vi skal utvikle generell motstandsdyktighet overfor ideologisk indoktrinering og politisk propaganda.

Den etiske funksjonen: respekt

\footnotetext{
${ }^{13}$ Jane Mansbridge m.fl.: «A Systemic Approach to Deliberative Democracy», 11.

${ }^{14}$ John Rawls, Collected Papers. Cambridge, Mass.: Harvard University Press 1999, 434.

${ }^{15}$ Hélène Landemore, «Beyond the Fact of Disagreement: The Epistemic Turn in Deliberative Democracy», i Social Epistemology 2017, 31, nr. 3.

${ }^{16}$ Christian F. Rostbøll, «Emancipation or Accommodation? Habermasian vs. Rawlsian Deliberative Democracy», i Philosophy and Social Criticism, 34, nr. 7, 2008.
} 
Det siste idealet jeg vil fremheve i den deliberative visjonen, er etisk, og sier noe om den gjensidige respekten som politisk uenige borgere og politikere skylder hverandre. Medlemmer av en deliberativ politisk kultur, kan vi si, forventes å tilskrive hverandre den som samme moralske statusen som frie og like medlemmer av det politiske fellesskapet. ${ }^{17}$ Dette betyr som minimum at de ikke betrakter hverandre som passive objekter for lovgivning, men som aktive, rasjonelle subjekter som innehar både en rett og en evne til å delta i politikk og samfunnsliv. Å styrke dette etiske båndet på tvers av livssyn, etnisitet og politiske fraksjoner kan dermed betraktes som den «etiske funksjonen» til demokratisk deliberation. ${ }^{18}$

På den ene siden er det pragmatisk klokt å kultivere respekt ettersom det muliggjør politisk samarbeid og rasjonell diskusjon, på tross av uenighet, mens manglende respekt fører oss inn i spiraler av mistillit og uløselige konflikter. På den andre siden er gjensidig respekt et moralsk gode i seg selv, et gode som er implisitt til stede i selve den deliberative interaksjonen. Når jeg lytter til deg med en prinsipiell åpenhet for å bli overbevist av gode argumenter, da respekter jeg både din rett til å komme til orde og din evne til å bidra til diskusjonen qua fornuftsvesen. Når en demokratisk majoritet svarer på minoritetens kritikk med argumenter - ikke med krenkelser eller trusler - da respekterer den minoritetens «rett til rettferdiggjørelse», ${ }^{19}$ dvs. retten til å motta en begrunnelse for avgjørelser man opponerer mot. Ettersom enhver begrunnelse er kritiserbar, holdes døren på denne måten åpen for en framtidig gjenåpning av diskusjonen, noe som igjen uttrykker respekt for den tapende minoritetens rett til deltagelse og opposisjon. Vi kan derfor si at deliberasjon ideelt sett forutsetter respekt, men også produserer respekt.

\section{Sammenheng og konflikt}

Selv om de tre deliberative funksjonene, den demokratiske, den epistemiske og den etiske, er analytisk distinkte kategorier, så henger de uløselig sammen i enhver politisk praksis, noe som også betyr at de kan komme i intern konflikt. ${ }^{20}$ Et eksempel på at de beriker hverandre positivt, kan være at økt inklusjon fører til en mer opplyst debatt ettersom nye perspektiver fører til bedre forståelse av en sak. Et eksempel på

\footnotetext{
${ }^{17}$ Jürgen Habermas, Between Naturalism and Religion. Cambridge: Polity Press 2008, 293.

${ }_{18}^{18}$ Jane Mansbridge m.fl.: «A Systemic Approach to Deliberative Democracy», 11.

${ }^{19}$ Rainer Forst, The Right to Justification. Elements of a Constructivist Theory of Justice. New York: Colombia University Press 2011.

${ }^{20}$ Jane Mansbridge m.fl.: «A Systemic Approach to Deliberative Democracy».
} 
det motsatte kan være at $\varnothing \mathrm{kt}$ inklusjon forringer debattens etiske eller epistemiske kvalitet fordi de som inkluderes, sprer hatefulle synspunkter eller fremfører feilaktige påstander med stor overbevisningskraft. For å ta et eksempel: Høyrepopulismens fremvekst i vestlige demokratier har nok gitt en stemme til borgere som før har vært fremmedgjort fra politikk, dvs. grupper som har følt at deres holdninger - eller «folk som dem»-ikke var ønsket i det politiske etablissementet. Dette er i utgangspunktet noe deliberative demokrater bør se som et gode fordi det $\emptyset$ ker inklusjonen. Samtidig har deler av høyrepopulismen, godt hjulpet av internett og sosiale medier ${ }^{21}$ bidratt til å normalisere påstander som virker ødeleggende på den etiske og den epistemiske funksjonen: Påstander som angriper minoriteters og marginaliserte gruppers likeverd (den etiske funksjonen), eller sår tvil om vitenskapelig veldokumenterte fakta, for eksempel når USAs president, Donald Trump, avviser den klimavitenskapelige konsensusen som et «kinesisk påfunn» (den epistemiske funksjonen). ${ }^{22}$

\section{Den agonistiske modellen (Ernesto Laclau og Chantal Mouffe)}

Hvordan bør en deliberativ tilnærming, som er bekymret for inklusiviteten, den epistemiske kvaliteten og den etiske respekten i demokratiske prosesser, definere begrepet «populisme»? Mitt eget svar på dette spørsmålet er at populisme bør forstås som en form for politisk retorikk som kan anta svært ulike former, avhengig av dens logos (ideologiske innhold), ethos (beskrivelse av den som taler) og pathos (følelsesmessige appell). Noen av disse er prinsipielt uforenlige med det deliberative demokratiidealet, og har en skadelig innvirkning på de tre deliberative funksjonene, mens andre har en rekke gunstige effekter. Jeg utvikler denne forståelsen gradvis gjennom en kritisk dialog med de to mest innflytelsesrike populismedefinisjonene i moderne politisk teori, henholdsvis den agonistiske modellen (Ernesto Laclau og Chantal Mouffe) og den ideologiske modellen (Cas Mudde og Cristóbal Rovira Kaltwasser).

Laclau forstår populisme som en politisk logikk som gjør seg gjeldende hver gang en regjerende makt ikke klarer å tilfredsstille en rekke «krav» («demands»). Når

\footnotetext{
${ }^{21}$ Benjamin Moffit: The Global Rise of Populism: Performance, Political Style, and Representation. Stanford University Press 2016, s. 88 - 94; Yasha Mounk: The People vs. Democracy: Why Our Freedom is in Danger \& How to Save It. Harvard University Press 2018, s. 137 - 150.

${ }^{22}$ David Volodzko: "Trump's Climate Denial Is A National Security Threat", Forbes 23.2 2019.
} 
et krav er utilfredsstilt $i$ et politisk system (for eksempel et krav om materiell omfordeling) og kommer i kontakt med andre utilfredsstilte krav (for eksempel krav om politisk inkludering eller kulturell anerkjennelse), oppstår det en «kjede av likeverdighet» mellom forskjellige krav, dvs. at forskjellige grupper danner en felles, antagonistisk front mot «systemet» eller «makteliten». ${ }^{23}$ En slik front kan imidlertid bare dannes gjennom identifikasjon med en leder som inkarnerer gruppens krav: «the symbolic unification of the group around an individuality [...] is inherent to the formation of a 'people'». ${ }^{24}$

Når populistiske ledere identifiserer slike utilfredsstilte krav som «folkets krav» og setter folket opp mot «makthaverne», uttrykker han eller hun ikke hvem folket egentlig er, men konstruerer et nytt folk gjennom en diskursiv praksis: «political practices do not express the nature of social agents but, instead, constitute the latter». ${ }^{25}$ Chantal Mouffe, som slutter seg til Laclaus modell, definerer derfor populisme som «a discursive strategy of constructing a political frontier dividing society into two camps and calling for the mobilization of the 'underdog' against 'those in power'». ${ }^{26}$ Jeg kaller dette den «agonistiske» modellen (gresk: agone = kamp, konflikt) ettersom både Laclau og Mouffe ser populistisk politikk som en permanent kamp mellom politiske identitetsgrupper og deres ledere, og fordi Mouffe selv beskriver posisjonen som agonistisk. ${ }^{27}$

Den politiske appellen til en konflikt mellom «folket» og «makthaverne» (alternativt «systemet» eller «eliten») er ansett som et definerende trekk ved populistisk politikk i mesteparten av den akademiske litteraturen, inkludert den retoriske tilnærmingen jeg forsvarer i det følgende. ${ }^{28}$ Dette er altså en definisjon jeg deler med den agonistiske modellen. Noe annet jeg deler, er Mouffes karakteristikk av populisme som en «diskursiv praksis»: Populistisk retorikk, slik jeg forstår den,

\footnotetext{
${ }^{23}$ Ernesto Laclau, On Populist Reason. London: Verso 2005, 73-75. Chantal Mouffe bygger direkte på Laclau i sin For a Left Populism. London: Verso 2018.

${ }^{24}$ Laclau, On Populist Reason, 100.

${ }^{25}$ Laclau, «Populism: What's in a Name?», i Fransisco Panizza (red.), Populism and the Mirror of Democracy. London: Verso 2005, 33.

${ }^{26}$ Mouffe, For a Left Populism, 11.

${ }^{27}$ Ibid.

${ }^{28}$ For eksempel Jan-Werner Müller, What Is Populism? Philadelphia: University of Pennsylvania Press 2016; Benjamin Moffitt, The Global Rise of Populism. Performance, Political Style, and Representation. Stanford: Stanford University Press 2016: Cas Mudde og Cristóbal Rovira Kaltwasser, Populism. A Very Short Introduction. Oxford: Oxford University Press 2017; Rogers Brubaker, «Why Populism?», i Theory and Society 46, 2017. (Se også oversettelse av Brubakers artikkel i dette nummeret av Agora.)
} 
handler nettopp om å foreta en politisk handling (praksis) gjennom en bestemt form målrettet språkbruk (diskurs). Mouffes definisjon samsvarer i denne betydningen med den «diskursive vendingen» i populismeforskningen, ${ }^{29}$ en vending som fokuserer bredt på diskursive og stilistiske trekk som kjennetegner populistisk politikk på tvers av kontekst og ideologisk ståsted.

En kritikk som har vært fremsatt mot den agonistiske modellen, er at den er for vag. Om enhver maktkritikk i «folkets» navn er populisme, blir det vanskelig å se forskjell på populisme og ikke-populisme, hevdes det. Det kan til og med hevdes at alle politiske prosjekter, ifølge denne posisjonen, dypest sett er populistiske, noe Laclau selv synes å bekrefte når han sier at politikk og populisme er det samme: «does not populism become synonymous with politics? The answer can only be affirmative». ${ }^{30}$ Vergara kritiserer derfor Laclau for å gjøre populisme til «alt og ingenting». ${ }^{31}$ Mudde og Kaltwasser hevder tilsvarende: «Laclau's theory of populism is, on the one hand, extremely abstract, and on the other hand, it proposes a concept of populism that becomes so vague and malleable it loses much of its analytic utility.» ${ }^{32}$

Mitt eget syn er imidlertid at denne kritikken ikke helt treffer. Det er riktig at den agonistiske definisjonen, helt bevisst, er bred. Dette skyldes at den skal dekke over vidt forskjellige politiske prosjekter som har det til felles at de kombinerer eliteog systemkritikk med et forsvar for «folket». Men populisme, for Laclau og Mouffe, er samtidig radikal i den forstand at den lover et reelt brudd med det bestående: «populism consists in postulating a radical alternative within the communitarian space, a choice in the crossroads on which the future of a given society hinges». ${ }^{33}$ Dette kjennetegnet synes å være velegnet til å avgrense populistisk retorikk fra ikkepopulistisk.

Dette betyr ikke at populisme nødvendigvis er revolusjonær i betydningen «samfunnsomveltende». Som påpekt av Camila Vergara, er populistisk politikk sjelden radikal i den forstand at den krever et totalt systemskifte, men ofte reformistisk, dvs. at den søker en gradvis endring av bestemte forhold innenfor et

\footnotetext{
${ }^{29}$ Rogers Brubaker, «Why Populism?» 360.

${ }^{30}$ Laclau, «Populism: What's in a Name?», 47.

${ }^{31}$ Camila Vergara, «Populism as Plebeian Politics: Inequality, Domination, and Popular Empowerment», i The Journal of Political Philosophy, vol. 0, nr. 0, 2019, 10.

${ }^{32}$ Cas Mudde og Cristóbal Rovira Kaltwasser, «Populism and (Liberal) Democracy», i Cas Mudde og Cristóbal Rovira Kaltwasser (red.), Populism in Europe and the Americas. Threat or Corrective for Democracy. Cambridge: Cambridge University Press 2012, 7.

${ }^{33}$ Laclau, «Populism: What's in a Name?», 47.
} 
eksisterende system. ${ }^{34}$ Et av Vergaras eksempler er det spanske venstrepartiet Podemos, som har fremmet krav om nasjonalisering av vannkraftverker, beskatning av de rikeste, og heving av minstelønnen, men uten å utfordre de grunnleggende premissene for en liberaldemokratisk samfunnsorden. Vi kan likevel slå fast at ikke enhver politisk appell til «folket» eller til «forandring» er populistisk. Som Brubaker sier det: «The resonance of populist rhetoric depends [...] on a claim to exceptionality, a claim to be fundamentally different from politics as usual. $»^{35}$

Den agonistiske modellen er likevel ikke uproblematisk, sett fra et deliberativt perspektiv. Problemet er at den insisterer på (a) at populisme handler om at en del av befolkningen gjør kravet på å være hele folket, samt (b) at dette kravet enten kan være en ressurs for, eller en trussel mot, demokratiet, avhengig av dets politiske innhold. Laclau er den som mest eksplisitt beskriver populismens pars pro toto-logikk, der en antatt undertrykt gruppe, eller sammenslutning av grupper, erklærer den resterende befolkning for «illegitim»: «In order to have the 'people' of populism, we need [...] a plebs [an underprivileged group] who claims to be the only legitimate populus - that is, a partiality which wants to function as the totality of the community». ${ }^{36}$ Mouffe, som slutter seg til Laclaus modell uten å ta avstand fra denne logikken, skiller i tillegg mellom på den ene siden en høyrepopulistisk og autoritær versjon, som fortolker «folket» på en fremmedfiendtlig og ekskluderende måte, og på den andre siden en venstrepopulistisk versjon, der «folket» er et inkluderende prosjekt, bestående av forskjellige fraksjoner av underprivilegerte grupper.

Jeg er enig med Mouffe $\mathrm{i}$ at appellen til «folket» kan være inkluderende fremfor ekskluderende. Som Jan-Werner Müller sier det: Politiske krav kan gjerne ha formen «vi er også folket», men ikke formen «bare vi er folket». ${ }^{37}$ Problemet med Mouffes versjon av den agonistiske modellen er at hun ikke har frigjort seg fra Laclaus forutsetning om at en del av den faktiske befolkningen må ekskluderes i den populistiske logikken. Det er i hvert fall slik jeg leser postulatet om at «folket» i den venstrepopulistiske varianten er en «discursive construction $[\ldots]$ whose unity is secured by the identification with a radical democratic conception of citizenship and a common opposition to the oligarchy». ${ }^{38}$ Om man insisterer på at «folket» består av de

\footnotetext{
${ }^{34}$ Vergara, «Populism as Plebeian Politics: Inequality, Domination, and Popular Empowerment», 17.

${ }^{35}$ Brubaker, «Why Populism?», 380.

${ }^{36}$ Laclau, On Populist Reason, 81.

${ }^{37}$ Müller, What Is Populism?, 98, min oversettelse

${ }^{38}$ Mouffe, For a Left Populism, 81.
} 
som identifiserer seg med en radikal, venstreorientert forståelse av medborgerskap og kampen mot oligarkiet, da ekskluderer man per definisjon store deler av den faktiske befolkning fra «folket», eksempelvis de som identifiserer seg med en nasjonalkonservativ forståelse av medborgerskap eller en nyliberal økonomisk visjon. Det er én ting å kritisere slike visjoner politisk, noe annet å insistere på at de som forsvarer dem, ikke er en del av «folket».

Problemet, sett fra et deliberativt ståsted, er ikke at Laclau og Mouffe oppmuntrer til generaliserende argumentasjon, dvs. argumenter som påberoper seg «allmennviljen» eller «folkets beste». Deliberative demokrater er enige i at politisk argumentasjon handler om generaliserbare interesser og det «felles gode» fremfor individuelle eller gruppespesifikke interesser, noe som betyr at gruppespesifikke krav må fremsettes med henvisning til mer allmenne prinsipper eller verdier. ${ }^{39}$ Problemet er at den agonistiske modellen forutsetter et mer radikalt skritt, der en sammenslutning av samfunnsgrupper ikke vil anerkjenne at det finnes deler av «folket» som ikke er en del av denne sammenslutningen. Lederen, som hevder å representere denne sammenslåingen, argumenterer altså ikke bare for at noe dypest sett er $\mathrm{i}$ «alles» interesse, eller for å inkludere ekskluderte grupper, men postulerer $\mathrm{i}$ tillegg at de som ikke deler et spesifikt syn på allmenviljen, ikke bør regnes som legitime medlemmer av «folket». Dette skjer eksplisitt hos Laclau og implisitt hos Mouffe.

Postulatet om at skillet mellom «folket» og «ikke-folket»bør defineres gjennom et spesifikt høyre- eller venstreorientert prosjekt, motsier selve det deliberative demokratiidealet. «Folkets vilje» er, for deliberative demokrater, alltid noe som er oppe til forhandling og diskusjon i en heterogen og pluralistisk politisk offentlighet, ikke noe partiske aktører kan ta til inntekt for sitt spesifikke politiske prosjekt. Om den politiske offentligheten domineres av påstander om hvem som er «folket» og hvem som ikke er, er det lett å se hvordan de tre deliberative funksjonene kan forringes eller trues.

Den demokratiske funksjonen trues dersom påstanden om å snakke på vegne av «folket» brukes som en unnskyldning for å avbryte den politiske

\footnotetext{
${ }^{39}$ Særbehandling av religiøse grupper kan for eksempel begrunnes med at dette er nødvendig for å skape reell likhet, ikke med henvisning til sannheten av spesifikke religiøse doktriner. Se for eksempel Jonas Jakobsen, «Moderate Inclusivism and the Conversational Translation Proviso: Revising Habermas' Ethics of Citizenship», i European Journal for Philosophy of Religion, vol. 11, nr. 4, 2019.
} 
kommunikasjonen med de som defineres som «ikke-folket» og deres representanter. I dette ligger en avvisning av behovet for diskusjon, lytting og gjensidig rettferdiggjøring på tvers av politiske fraksjoner, noe som gjør inkluderende offentlig diskusjon vanskelig, men legger omvendt til rette for politiske ekkokamre og «deliberative enklaver», slik vi kjenner dem fra sosiale medier som Twitter og Facebook. ${ }^{40}$ En mulig effekt av dette er et rent majoritetstyranni, dvs. at en etnisk, kulturell eller politisk majoritet definerer seg selv som «folket» og med god samvittighet unngår å ta innvendinger fra minoritetsgrupper seriøst.

Den epistemiske deliberative funksjonen skades ved at fortellingen om «folket» og «ikke-folket» antar stereotype eller propagandistiske former, for eksempel gjennom forsimplinger, overdrivelser, konspirasjonsteorier eller løgner, eller gjennom den mer eller mindre bevisste resirkuleringen av uprøvde fordommer om eliten eller makthaverne og deres politiske agenda.

Endelig skades den etiske funksjonen dersom «folket» defineres på en måte som er uforenlig med den gjensidige respekten som deliberative demokrater ser som både pragmatisk nødvendig og normativt påkrevd i demokratiske diskusjoner. Ved å utdefinere politiske motstandere som «illegitime», som ikke-folket, fratar man dem samtidig sin status som likeverdige politiske motstandere, dvs. som medlemmer av det samme politiske felleskapet med like rettigheter. Ved å postulere en kontroversiell (høyre- eller venstreorientert) visjon om hvem «folket» er, indikerer man samtidig at de som ikke slutter seg til denne visjonen, ikke har samme normative status som det «egentlige» folket. Slike overbevisninger kan, selv når de er underforståtte eller implisitte, ha en ødeleggende virkning på den gjensidige tilliten og anerkjennelsen som kjennetegner vellykkede deliberative relasjoner.

Jeg er klar over at en tenker som Mouffe ikke ønsker seg noen av disse konsekvensene, og vil være like kritisk til dem som jeg er. En grunnforutsetning i hennes agonistiske demokratiteori er nettopp at politiske motstandere anerkjenner hverandre som legitime selv om de har uforenlige politiske mål. Venstresiden skal med andre ord betrakte høyresiden som sin legitime politiske motstander og vice versa. Om den politiske kampen derimot utarter seg i retning av en kamp mellom «de gode» og «de onde», der partene fremstiller hverandre andre som illegitime og

\footnotetext{
${ }^{40}$ Cass R. Sunstein, \#republic. Divided Democracy in the Age of Social Media. Princeton: Princeton University Press 2017.
} 
benekter hverandres rett til å forsvare sin posisjon, degenerer agonismen til en form for «antagonisme», dvs. en venn/fiende-relasjon. ${ }^{41}$ Jeg er enig med Mouffe i at en viktig demokratisk oppgave er å tilveiebringe forutsetningene for at politisk uenighet kan anta en agonistisk form, samtidig som muligheten for antagonisme alltid er til stede. Jeg betrakter denne målsetningen som forenlig med idealet om deliberativt demokrati, ettersom Mouffes agonisme innebærer en «agonistisk debatt» der argumenter for og imot politiske prosjekter fremsettes i en kritisk offentlighet. Mitt poeng er imidlertid at Mouffes manglende distanse til Laclaus modell skaper et spenningsforhold mellom hennes populismeteori og hennes agonistiske demokratiteori. Om venstrepopulister insisterer på at «folket» er en gruppe som er forent gjennom et radikalt, venstreorientert prosjekt, risikerer de å bidra til en problematisk form for antagonisme: De fyrer opp under forestillingen om at den politiske frontlinjen står mellom «folket» og «ikke-folket», ikke mellom forskjellige politiske fraksjoner internt blant folket.

Mouffes venstrepopulistiske prosjekt kan etter mitt syn reddes ved å klargjøre hva venstrepopulister mener, eller bør mene, når de setter «folket» opp mot «makthavenerne». Rogers Brubaker har formulert en tredeling som kan være nyttig for dette formålet, nemlig mellom folket som vanlige folk («plebs»), som politisk suverent («demos») og som kulturelt eller etnisk distinkt («nasjon» eller «etnos»). ${ }^{42}$ Den siste betydningen assosieres typisk med høyrepopulisme. Den andre betydningen, folket som demos, er mer interessant i vår sammenheng fordi den åpenbart brukes av en rekke venstrepopulistiske aktører og partier. Å snakke på vegne av folket som «demos» handler typisk om å kreve en form for demokratisering eller gjendemokratisering av politiske beslutningsprosesser som har falt utenfor folkets kontroll. Det bør samtidig være klart at enhver form for populisme som hevder at «makthaverne» eller «eliten» ikke tilhører folket som «demos», er uforenlig med både deliberativt og agonistisk demokrati. Poenget for venstrepopulister bør være at vi alle stiller likt som medlemmer av demos, det politiske fellesskapet, noe som gir grunnlag for å kritisere strukturer og maktforhold som hindrer deltagelseslikhet, jf. den demokratiske deliberative funksjonen (inklusjon).

\footnotetext{
${ }^{41}$ Mouffe, For a Left Populism, 93.

42 Brubaker, «What is Populism?», 359.
} 
Den første betydningen, folket som plebs, er det etter mitt syn ikke noe i veien for at venstrepopulister kan bruke i en ekskluderende betydning. Mangemilliardærer lever som oftest i en annen «verden» enn middel- og underklassen, og har en rekke urettmessige privilegier når det gjelder å kunne påvirke politikken. Å påpeke dette fratar dem ikke noen politiske rettigheter (folket som demos), og ekskluderer dem heller ikke på bakgrunn av rase, kultur eller religion (folket som etnos).

Mitt poeng er ikke at venstrepopulister skal lage denne tredeling eller spesifisere hva de mener hver gang de snakker på vegne av «folket«». Jeg mener derimot at en politisk teori som hevder å forsvare venstrepopulisme, bør være tydelig på å skille mellom de tre dimensjonene, og spesifisere at forestillingen om «folket» aldri bør brukes ekskluderende i de to siste betydningene.

\section{Den ideologiske modellen: Cas Mudde og Rovira Kaltwasser}

Cas Mudde og Cristóbal Rovira Kaltwasser er kjent for å forsøke å formulere et empirisk anvendelig populismebegrep som muliggjør komparative analyser på tvers av region, politisk ideologi og kontekst. Deres «ideologiske» minimaldefinisjon har fått stor innvirkning på populismeforskningen i europeisk statsvitenskap og politisk teori:

[populism is] a thin centered ideology that considers society to be divided into two homogenous and antagonistic groups: «the pure people» and «the corrupt elite», and which argues that politics should be an expression of the volonté general (general will) of the people. ${ }^{43}$

At populisme er en tynn ideologi, vil si at den aldri er bærende i et politisk prosjekt, men parasittær på mer substansielle eller «tykke» ideologier, slik som sosialisme, agrarianisme, nyliberalisme, islamisme eller nasjonalisme. «Eliten» og «folket» vil da bli definert forskjellig av forskjellige ledere og partier; sosialistiske populister kan for eksempel snakke om en kamp mellom «oligarkene» versus «det hardt arbeidende folket», og høyrepopulister kan snakke om den politiske og kulturelle eliten som ikke forstår «vanlige folk» og lar fremmedkulturelle krefter innta nasjonen. ${ }^{44}$ Mudde og

\footnotetext{
${ }^{43}$ Cas Mudde, «The Populist Zeitgeist», i Government and Opposition 39, nr. 4, 2005, 543.

${ }^{44}$ Ibid., 545.
} 
Kaltwasser understreker at populisme kan ha gunstige effekter på inklusjonen i et demokrati, ved at marginaliserte grupper blir hørt og representert. Populisme kan med andre ord ha en demokratiserende effekt, særlig i autoritære regimer med svake demokratiske institusjoner. ${ }^{45}$ De hevder samtidig at den populistiske ideologien ikke aksepterer legitim politisk opposisjon (populisten snakker på vegne av hele folket, noe som utelukker at andre kan gjøre det samme) og karakteriserer derfor all populisme som «antipluralistisk». ${ }^{46}$ Populisme, ifølge den ideologiske definisjonen, blir dermed uforenlig med liberalt demokrati, også i den deliberative varianten jeg forsvarer i denne artikkelen. Med utgangspunkt i det deliberative idealet er en velfungerende, kritisk offentlighet alltid pluralistisk, og saklig politisk opposisjon alltid legitim. Det jeg kalte den «demokratiske funksjonen» (inklusjon) forutsetter at minoriteter og marginaliserte grupper har en sjanse til å utfordre majoritetsmakten, enten direkte eller via valgte representanter.

Det er mulig at man vinner en analytisk klarhet ved å definere populisme som anti-pluralistisk, ved at dette gjør det lettere å kartlegge og sammenligne populisme som politisk fenomen på tvers av ideologiske og nasjonale kontekster. Det kan samtidig hevdes at nettopp denne klarheten utelukker en rekke interessante politiske fenomener fra analysen, både på høyre- og venstresiden. Det er eksempelvis vanlig å hevde at det norske Fremskrittspartiet (FrP) har klare høyrepopulistiske trekk, idet det kombinerer «motstand mot innvandring, en utpreget lov og orden-profil, samt en folkelig stil og elitekritikk». ${ }^{47}$ Det er likevel ikke riktig å hevde at FrP generelt sett betrakter eliten som korrupt eller at partiet er anti-pluralistisk, verken i den betydning at det betrakter folket som homogent (for eksempel etnisk rent eller religiøst ensartet), eller at det ikke anerkjenner legitim politisk opposisjon. Om vi tar den ideologiske definisjonen på alvor, har Frp altså ikke noe med høyrepopulisme å gjøre, på samme måte som de eksemplene jeg har gitt på venstrepopulisme (Bernie Sanders i USA og Podemos i Spania) ikke har noe med populisme å gjøre. Dette er uheldig, fordi det hindrer oss i å analysere diskursive og stilistiske likhetstrekk mellom aktører på høyre- og venstresiden, aktører som utfordrer sentrum-høyre så vel som sentrumvenstre.

\footnotetext{
${ }^{45}$ Mudde og Kaltwasser, Populism. A Very Short Introduction, kapittel 5.

${ }^{46}$ Mudde, «The Populist Zeitgeist».

${ }^{47}$ Anders Ravik Jupskås: «Høyrepopulistiske partier», i Store Norske Leksikon 2019: https://snl.no/h\%C3\%B8yrepopulistiske_partier.
} 
Et annet problem med den ideologiske modellen er at den «tynne» populistiske ideologien ikke bare er noe populisten forsøker å få andre til å godta, men som noe han eller hun selv slutter seg til og tror på. Dette blir tydelig når Mudde og Kaltwasser beskriver populisme som en «verdensforståelse» eller et «mentalt kart» som farger populistens politiske virkelighetsoppfatning. ${ }^{48}$ Problemet med dette er for det første at det er umulig å vite om en politisk aktør egentlig mener det han eller hun sier. Hvem vet om Trump faktisk mener det, når han sier at den politiske eliten er korrupt, eller om han sier det fordi det er populært? Min retoriske definisjon forholder seg her, av gode grunner, agnostisk til hva som foregår inne i hodet på populisten. Jeg er enig med Mudde og Kaltwasser i at motsetningen mellom «det rene folket» og «den korrupte eliten» er populistisk, og jeg inkorporerer denne motsetningen i min egen definisjon av sterk populisme (se neste hovedavsnitt). Samtidig fastholder jeg at det er teoretisk uholdbart, og irrelevant for empirisk forskning, å postulere noe om hvilket verdenssyn populister har, eller hvilket «mentalt kart» de opererer ut fra. Det som er viktig, sett fra et deliberativt perspektiv, er det som blir sagt og de virkninger dette har i den politiske offentligheten.

Det største problemet med den ideologiske tilnærmingen er imidlertid at den synes å implisere en enten/eller-logikk som deler politiske aktører opp i «populister» og «ikke-populister». En populistisk verdensforståelse er i sakens noe man enten har eller ikke har. Dette er problematisk såfremt man mener, slik jeg gjør, at politiske aktører kan være mer eller mindre populistiske: Én politiker kan ha sterkere innslag av populistisk retorikk enn en annen, og den samme politikeren kan være mer eller mindre populistisk på forskjellige tidspunkter og i forskjellige kontekster. Den retoriske tilnærmingen jeg forsvarer i resten av denne artikkelen, er velegnet til å analysere populisme som et graduelt fenomen, nettopp fordi den ikke fokuserer på ideologi (noe som er statisk), men på spesifikke ytringer (noe som er skiftende og sammensatt). ${ }^{49}$ Man kan gjerne bruke min tilnærming til å kategorisere et politisk parti som populistisk i den betydning at det i høy grad anvender en populistisk retorikk, men ikke til å kategorisere noen som populist i den forstand at de slutter seg til en bestemt ideologi. Dermed unngår jeg å reprodusere det populistiske skillet

\footnotetext{
${ }^{48}$ Mudde og Kaltwasser, Populism. A Very Short Introduction, 5-6.

${ }^{49}$ Min kritikk av Mudde har flere ting til felles med Paris Aslanidis, «Is Populism an Ideology? A Refutation and a New Prespective», i Political Studies 64, nr. 15, 2016.
} 
mellom «oss, de liberale demokrater» og «dem, populistene», et skille som i stigende grad har fått en polariserende effekt i den politiske offentligheten de senere årene.

\section{Populisme som (svak eller sterk) retorikk: logos, ethos og pathos}

Jeg er selvsagt ikke den første som forsvarer en retorisk populismedefinisjon. Kazin definerer populisme i en amerikansk kontekst som «a persistent yet mutable style of political rhetoric», ${ }^{50}$ dvs. en polariserende språkbruk som anvendes av de som hevder å snakke for majoriteten av amerikanere. Jagers og Walgrave oppfatter populisme som «a communication frame that appeals to and identifies with the people», ${ }^{51} \mathrm{og}$ Canovan hevder at det eneste som forener populister, er deres «rhetorical style which relies heavily upon appeals to the people», 52 noe som innebærer at populisme er et spørsmål om stil mer enn om substans. Det som skiller mine analyser fra disse er for det første at jeg skiller mellom to former for populistisk retorikk: henholdsvis en sterk og svak utgave. Sterk populisme er per definisjon i konflikt med liberalt demokrati, og $\varnothing$ deleggende for en deliberativ politiske kultur. Den svake utgaven, derimot, er forenlig med liberalt demokrati og kan ha både positive og negative effekter på de tre deliberative grunnfunksjonene (inklusjon, opplysning og respekt). For det andre er min karakteristikk av både den svake og den sterke populismen basert på en fortolkning av Aristoteles' klassiske skille mellom tre retoriske grunnkategorier: logos (det som det argumenteres for), ethos (selvfremstilling) og pathos (følelsesmessig appell). ${ }^{53}$

\section{Logos}

Logos er, i Aristoteles' lære om retorikken, knyttet til overbevisning gjennom fornuft og argumentasjon, og inkluderer både den saken det fokuseres på, og de bevismidlene som taleren anvender. Slik jeg bruker utrykket her, handler populismens logos imidlertid først og fremst om det budskapet eller ideologiske innholdet som avsenderen vil ha mottakeren til å akseptere, dvs. det sannhetspostulatet som fremmes gjennom populistisk argumentasjon.

\footnotetext{
${ }^{50}$ Michael Kazin, The Populist Persuasion. An American History. Ithaca og London: Cornell University Press 1995.

${ }^{51}$ Jan Jagers og Stefaan Walgrave, «Populism as Political Communication Style: An Empirical Study of Political Parties' Discourse in Belgium», i European Journal of Political Research, 46, nr. 3, 1995.

${ }^{52}$ Margaret Canovan: «People, Politicians and Populism», i Government and Opposition 19, nr. 3, 1984.

${ }^{53}$ Aristoteles, Rhetoric. Dover Publications 2004.
} 
Den populistiske logos kommer til uttrykk ved at man appellerer til en motsetning mellom «folket» og «eliten» (alternativt «systemet» eller «makthaverne»). I den sterke versjonen uttrykkes dette i form av anti-pluralistiske og anti-demokratiske postulater: Påstander om at «folket» er homogent (anti-pluralistisk) eller at politiske opponenter er folkets fiender (anti-demokratisk). Påstanden om at «folket» er homogent, støtter opp om forskjellige narrativer og ideologier som har det til felles at de stempler bestemte befolkningsgrupper som en trussel mot det «egentlige» eller «ekte folket», for eksempel muslimer, ateister, homoseksuelle eller feminister. I europeisk og amerikansk sammenheng er vi best kjent med den høyrepopulistiske retorikken som forteller oss at «folket», forstått som en etnisk, kulturell eller nasjonal enhet, er truet av muslimsk innvandring. Det populistiske innslaget her består ikke i å kritisere islam eller spesifikke islamfortolkninger som religion, ei heller i påstanden om at vi trenger en restriktiv innvandringspolitikk, men i den konstruerte politiske konflikten mellom «muslimene» og «folket». Visse typer «islamkritikk» har en lignende stigmatiserende effekt, for eksempel når Donald Trump under sin valgkamp i 2016 sa at «islam hater oss». ${ }^{54}$ Når man presenterer Islam som en farlig og monolittisk ideologi, så antyder man samtidig at de som slutter seg til denne ideologien, også er farlige. Utpekingen av befolkningsgrupper som «ikke-folket» trenger imidlertid ikke være rettet mot minoriteter eller sårbare grupper. Når Nigel Farage beskrev Brexit-avstemningen i 2016 som en seier for det «ekte folket», sa han samtidig at nær halvparten av stemmegiverne ikke er «ekte briter».

Slik retorikk skader åpenbart den etiske deliberative funksjonen: «Respekt» blir definert på en sekterisk måte, som ekskluderer bestemte grupper fra den på et moralsk sett arbitrært grunnlag. I tillegg skades den epistemiske funksjonen, fordi fortellingen om det homogene folket og dets fiender bare kan opprettholdes gjennom en propagandistisk spredning av kulturelle eller etniske stereotypier og manipulert informasjon. Om denne retorikken blir dominerende i en politisk kultur, vil også den demokratiske funksjonen skades, ettersom de gruppene som stemples som «folkets fiender», ikke vil ha tilnærmet like betingelser for demokratisk deltagelse. Når Donald Trump fremhever islam som det amerikanske folkets fiende, til stor begeistring for

\footnotetext{
${ }^{54}$ Jenna Johnson og Abigail Hauslohner, «'I think Islam hates us’: A Timeline of Trump’s Comments about Islam and Muslims», i The Washington Post, 20. mai 2017.
} 
hans tilhengere, er det ikke rart om amerikanske muslimer tenker seg om to ganger før de stiller til valg eller deltar i politiske debatter.

Påstanden om at politiske opponenter er illegitime, er like skadelig. Vi har her å gjøre med påstander om at politiske motstandere ikke bare er på villspor rent politisk, men at de også har skadelige eller folkefiendtlige hensikter. Ta som eksempel det greske, venstrepopulistiske partiet Syriza, som bl.a. har beskrevet hjemlige opponenter som Tysklands «femtekolonne» og karakterisert EU som «terrorister». ${ }^{55}$ Eller ta Venezuelas tidligere president Hugo Chavez’ påstander om at hans opponenter var «alliert med djevelen». ${ }^{56}$ Denne form for delegitimering av politisk opposisjon er vanskelig å forene med den deliberative tanken om at demokratisk legitimitet springer ut av politiske debatter mellom alle berørte parter (jf. den demokratiske funksjonen).

Det forholder seg imidlertid annerledes med det jeg kaller svak bruk av populistisk logos. Den svake bruken appellerer også til forestillingen om at folket et truet av maktfulle krefter, både vertikalt (f.eks. politiske, kulturelle eller økonomiske eliter) og horisontalt (eksterne grupper og aktører, for eksempel EU, islamisme eller global kapitalisme). ${ }^{57}$ Forskjellen er at den svake bruken holder seg innenfor rammene av et liberaldemokratisk normativt univers, og derfor ikke står i direkte konflikt med det deliberative demokratiidealet. For å være mer presis, den svake populistiske logos spiller på konflikten mellom folket og dets fiender, men utelukker ikke noen fra folket som «demos» (politisk fellesskap) eller «etnos» (etnisk eller nasjonalt-kulturelt fellesskap), i hvert fall ikke på den antipluralistiske og antidemokratiske måten som kjennetegner den sterke populismen. Den svake populismen er derfor forenlig med bred livsynspluralisme, demokratisk opposisjon og basale demokratiske spilleregler.

Den svake bruken av populistisk logos kan både ha skadelige og gunstige innvirkninger på de tre deliberative funksjonene. Et eksempel på den mer skadelige bruken mener jeg er Sylvi Listhaugs famøse Facebook-innlegg om at «Ap [Arbeiderpartiet] mener terroristenes rettigheter er viktigere enn nasjonens

\footnotetext{
${ }^{55}$ Mudde og Kaltwasser, Populism. A Short Introduction, 82.

${ }^{56}$ Gjengitt fra Moffit, The Global Rise of Populism: Performance, Political Style and Representation, 146.

${ }^{57}$ Brubaker, «Why Populism?», 362-364.
} 
sikkerhet». ${ }^{58}$ Oppdateringen, som førte til hennes avgang som justisminister fordi hun aldri klarte å beklage den, benekter ikke at Ap er et legitimt opposisjonsparti. Den kan imidlertid leses som en påstand om at Ap ikke bryr seg om «folket», fordi partiet ikke bryr seg om landets sikkerhet. Denne lesningen er ikke unaturlig gitt den generelle fortellingen innenfor deler av FrP om at Ap og venstresiden nærmest har ødelagt Norge gjennom ukontrollert innvandring. ${ }^{59}$ I verste fall nører slik retorikk opp under konspirasjonsteorier om Ap som «landssvikere» og «interne fiender», i stil med den hatefulle ideologien som motiverte terrormassakren på partiets ungdomsorganisasjon på Utøya den 22. juli $2011 .{ }^{60}$ Det sier seg selv hvilke skadelige innvirkninger slike forestillinger har på det deliberative demokratiet, særlig hvis de normaliseres $\mathrm{i}$ mainstream partipolitikk. I sitt selvforsvar la Listhaug vekt på at innlegget var rettet mot en bestemt sak om fratakelse av visse rettigheter for folk som er mistenkt for terrorvirksomhet, og ikke handlet om 22. juli. Som justisminister bør man likevel spørre seg selv hvilken retorisk signaleffekt slike innlegg har, ikke minst når de ledsages av et skremmende bilde av maskerte terrorister, klare til angrep (se avsnittet om pathos).

Poenget mitt er ikke at høyresiden aldri bruker den svake populistiske logos på en berikende måte, sett fra et deliberativt perspektiv. Jeg utelukker for eksempel ikke at den tidvis skarpe retorikken om innvandring og islam har bidratt til å sette fokus på reelle utfordringer relatert til integrering og kulturell diversitet (den epistemiske dimensjonen), og dermed har introdusert saksfelt som mange borgere $\emptyset$ nsker å snakke om (den demokratiske funksjonen). Det er likevel ingen hemmelighet at min deliberative tilnærming, når den skal vurdere om svak populistisk retorikk har gode eller dårlige effekter for demokratiet, står nærmere det som i europeisk og amerikansk sammenheng kan beskrives som venstrepopulisme. Venstrepopulistiske partier fokuserer typisk på strukturelle forhold som opptar (eller bør oppta) deliberative demokrater, for eksempel hvordan rasisme, misogyni og muslimhat preger demokratiske debatter negativt (den etiske funksjonen), eller hvordan $\varnothing$ konomiske privilegier og materiell skeivfordeling innvirker negativt på den demokratiske deltagelsen og folkesuvereniteten (den demokratiske funksjonen). Når Bernie Sanders

\footnotetext{
${ }^{58}$ Sitert fra NRK: «Har gått gjennom Listhaugs angrep på Ap», 12. mars 2018: https://www.nrk.no/norge/har-gatt-gjennom-listhaugs-angrep-pa-ap-1.13958006

59 Jf. her f.eks. Christian Tybring-Gjedde og Kent Andersen, «Drøm fra Disneyland», i Aftenposten 25. august 2010 .

${ }^{60}$ Jf. Sindre Bangstad, Anders Breivik and the Rise of Islampphobia. London: Zed Books 2014.
} 
hevder at «the American people are sick and tired of billionaires [Donald Trump and Michael Bloomberg] buying elections!», ${ }^{61}$ så spiller han på populistisk vis på konflikten mellom «folket» og «oligarkene», men peker samtidig på et reelt problem: sammenhengen mellom $\varnothing$ konomisk og politisk makt i dagens USA.

Venstrepopulisme, i vestlig sammenheng, anerkjenner dessuten den klimavitenskaplige konsensusen, noe mange høyrepopulister ikke gjør.

Venstrepopulisten Sanders har klimautfordringen høyt på sin politiske dagsorden, mens høyrepopulisten Trump latterliggjør denne utfordringen når han twitrer om hvor kaldt det er i New York og spør hvor den globale oppvarming blir av. ${ }^{62}$ Om vi antar at klimavitenskapen har rett, kan vi dermed si at Sanders motsatt Trump bidrar til en opplysende debatt om klima og miljø (den epistemiske funksjonen).

\section{Ethos}

Ethos handler om selvfremstiling, dvs. om måten man presenterer seg selv på når man vil overbevise andre om noe. For Aristoteles er en overbevisende retoriker en som gir inntrykk av å ha de tre egenskapene areté (moralsk kvalitet), phronesis (sunn fornuft) og eunoia (velvilje). I vår tid, som på Aristoteles’ tid, er dette noe enhver vellykket politiker i større eller mindre grad er i stand til. Det populistiske innslaget handler derfor om hvordan disse kvalitetene nærmere bestemt framstilles.

Den empirisk orienterte populismeforskningen angir en rekke interessante fellestrekk mellom selvfortellingen til politiske ledere som vanligvis blir betraktet som populister, slik som Geert Wilders (Nederland) og Hugo Chávez (Venezuela). Benjamin Moffit peker på at lederens «sunne fornuft» ofte blir identifisert med det «folkelige», forstått som det som «vanlige folk»-ikke eksperter, akademikere eller profesjonelle politikere - legger i dette. Samtidig viser han hvordan den populistiske lederen må finne en balanse mellom å fremstå som alminnelig og spesiell: Hun er alminnelig fordi hun representerer «vanlige folk», men ekstraordinær fordi hun har særlige forutsetninger for å lede kampen mot makteliten. ${ }^{63}$ Et eksempel på dette er Donald Trumps kombinasjon av en bestemt forståelse av folkelighet (politisk ukorrekt oppførsel, preferanse for Fast Food og TV, osv.) med en grandios selvfortelling,

\footnotetext{
${ }^{61} \mathrm{https}: / / \mathrm{www}$.huffpost.com/entry/rival-democrats-accuse-mike-bloomberg-of-trying-to-buyelection_n_5e4a0c50c5b64433c6185f06

${ }^{62}$ David Volodzko, «Trump's Climate Denial Is A National Security Threat», i Forbes 23. februar 2019.

${ }^{63}$ Moffitt, The Global Rise of Populism, 55.
} 
herunder påstanden om å være «a very stable genius». ${ }^{64}$ Slike selvframstillinger får tidvis et religiøst preg, som da Italias Silvio Berlusconi hevdet å være «the Jesus Christ of Politics» i et intervju med CNN i $2006 .^{65}$

Vi kan etter mitt syn snakke om en sterk og en svak bruk av den populistiske ethos. Den sterke bruken identifiserer lederen med «folket», dvs. at lederen gjør krav på å inkarnere «folkets vilje» i sin person og sine handlinger. Et klassisk eksempel på dette er den tyrkiske presidenten Recep Tayyip Erdoğan, som i nasjonalforsamlingen uttaler at «vi er folket», for deretter å henvende seg til opposisjonen med spørsmålet: «Hvem er dere?» ${ }^{66}$ Eller som venstrepopulisten Hugo Chávez sa det: «I am not an individual, I am the people.» ${ }^{67}$ Den sterke ethos gjør lederen i stand til å påstå at de som argumenterer mot ham eller henne, argumenterer mot selve «folket». Om lederen allerede vet hva folket ønsker og har bruk for, da trenger folket ikke å opplyse seg selv i en kritisk offentlighet (den epistemiske funksjonen). Om lederen kan snakke på vegne av alle medlemmer av «folket», da trenger ikke opposisjonen å bli hørt (den demokratiske funksjonen).

Svak populistisk ethos, derimot, postulerer ikke at lederfiguren er en direkte manifestasjon av «folkets vilje». Likevel tillegger den lederen ekstraordinære egenskaper og skaper begeistring for hans eller hennes person. Et problematisk eksempel på dette er Trump påstand om at bare han kan bringe USA tilbake til fortidens storhet: «Only I can fix it.» ${ }^{68}$ Skal vi tro Trump, er han altså den eneste kvalifiserte politiske lederen, en leder som egenhendig kan løfte folket ut av sin elendighet. Denne bruken av ethos skader den epistemiske deliberative funksjonen på to måter. For det første undermineres den generelle tilliten til eksperter og vitenskap, ettersom befolkningsgrupper forledes til å tro at lederen er så kompetent at han eller hun ikke har bruk for ekspertise og forskningsbasert rådgiving. For det andre forringes den offentlige forståelsen av hva et demokrati er for noe: I stedet for å fremme en forståelse av demokrati som et folkestyre der makt og kompetanser er delt, dvs. at ingen enkeltperson besitter dem fullstendig, skapes et personalisert bilde av den demokratisk valgte lederen som handler autonomt på folkets vegne.

\footnotetext{
${ }^{64}$ William Cummings, «Trump says he's 'so great looking and smart, a true Stable Genius' in tweet bashing 2020 Dems», i USA Today, 11. mai 2019.

${ }^{65}$ Moffit, The Global Rise of Populism, 63.

${ }^{66}$ Sitert fra Jan-Werner Müller, What Is Populism?, 3.

${ }^{67}$ Moffit, The Global Rise of Populism, 51.

${ }^{68}$ David Graham, « 'America First': Donald Trump's Populist Inaugural Address», i The Atlantic, 20. januar 2017.
} 
Det er samtidig klart at sterke eller inspirerende ledere ofte styrker det demokratiske engasjementet. Som Mouffe påpeker, er affektiv binding til karismatiske ledere et viktig element i mange vellykkede sosiale og politiske bevegelser, ${ }^{69}$ slik som Bernie Sanders' demokratiske sosialisme i USA. Sanders fremstiller i høy grad seg selv som handlekraftig, moralsk og kompetent, og fronter seg selv som mannen som kan slå Trump. Han har imidlertid aldri sagt noe som ligner på Trumps «only I can fix it»: Slagordet på Sanders kampanjehjemmeside er «Not Me. Us.». ${ }^{70}$ Sanders griper ikke til guddommelige metaforer, genierklærer seg selv, eller gir inntrykk av at hans individuelle person er svaret på befolkningens problemer. Hans bruk av populistisk ethos er derfor positiv snarere enn negativ: Delvis via sin personlige karisma og troverdighet har han klart å mobilisere store befolkningsgrupper politisk, herunder ungdommer og minoritetsgrupper (den demokratiske funksjonen).

\section{Pathos}

Pathos, den siste av Aristoteles' kategorier, handler om de følelser en taler forsøker å vekke i sitt publikum. Når Moffitt kritiserer retoriske populismemodeller for å ignorere følelser, ${ }^{71}$ er det altså feil, ettersom retorikken siden Aristoteles’ tid har vært opptatt nettopp av språkets evne til å vekke forskjellige typer emosjoner.

Deliberative teoretikere anerkjenner at politiske emosjoner spiller en betydningsfull rolle i demokratiske prosesser. Habermas, for eksempel, hevder at «negative» følelser som indignasjon og sinne og «positive» følelser som omsorg og empati alltid er til stede i større eller mindre grad i selve den deliberative interaksjonen. ${ }^{72}$ Det blir dermed feil når Mouffe hevder at Habermas ønsker å «utradere» følelser fra offentligheten, ${ }^{73}$ eller når Iris Marion Young argumenterer for å inkludere følelser $i$ tillegg til rasjonell debatt. ${ }^{74}$ Rasjonell debatt har alltid en emosjonell komponent, og emosjoner spiller derfor alltid en rolle i den demokratiske offentligheten. Det interessante i vår sammenheng er derfor ikke å forsvare eller

\footnotetext{
${ }^{69}$ Mouffe, For a Left Populism, 70.

${ }^{70} \mathrm{Se}$ https://berniesanders.com.

${ }^{71}$ Moffit, The Global Rise of Populism, 22.

72 Jürgen Habermas, «Discourse Ethics: Notes on a Program of Philosophical Justification», i Moral Consciousness and Communicative Action. Cambridge, Mass.: The MIT Press 1983.

${ }^{73}$ Mouffe, «Deliberative Democracy or Agonistic Pluralism».

${ }^{74}$ Iris Marion Young, Justice and the Politics of Difference. Princeton, New Jersey: Princeton University Press 2011.
} 
bekjempe «følelser i politikk» på et generelt plan, men å analysere mer spesifikt hvordan bestemte følelser vekkes i den politiske offentligheten på produktive eller problematiske måter.

Når populistiske politikere spiller på følelser av hat og frykt mellom legitime befolkningsgrupper, kan vi snakke om sterk populisme. Når jeg snakker om «legitime grupper», er det for å understreke at det kan være god grund til å frykte bestemte grupper, for eksempel ekstreme grupper som planlegger et terrorangrep (en ikkelegitim gruppe), men ikke til å frykte «muslimer» (en legitim gruppe) generelt. De hatefulle eller fryktbaserte følelsene jeg knytter til sterk populisme, er typisk konstruert på bakgrunn av det Jason Stanley kaller «falske ideologier» ${ }^{75} \mathrm{dvs}$. en form for diskursiv propaganda som brukes til å spre negative stereotyper om legitime befolkningsgrupper, for eksempel at de er løgnaktige, farlige, moralsk tilbakestående, seksuelt perverse eller voldelige.

Sterk høyrepopulistisk retorikk er kjent for å spille på ressentimentet i deler av befolkningen, mot både «liberale eliter» og kulturelle og sosiale minoriteter. ${ }^{76}$ Samtidig er det ikke slik at en enhver populistisk retorikk gjør dette, i hvert fall ikke om jeg har rett i at det gir mening å skille mellom en sterk og en svak variant. Om vi anvender dette skillet på populismens pathos, kan vi argumentere for at appeller til befolkningens følelser kan anta andre og mer gunstige former. Axel Honneth har for eksempel analysert hvordan moralske følelser som vrede og indignasjon utgjør selve drivkraften bak en rekke moderne frigjørelsesbevegelser, slik som kvinnebevegelsen, arbeiderbevegelsen og den amerikanske borgerrettighetsbevegelsen. ${ }^{77}$ Slike følelser oppstår ifølge Honneth når grupper av subjekter finner sammen i en felles opplevelse av å være utsatt for uberettiget ringeakt eller manglende anerkjennelse. Nå kaller Honneth ikke slike bevegelser for populistiske, men vi kan likevel si at venstrepopulister typisk spiller på noen av de samme erfaringene og følelsene, eksempelvis følelsen av indignert harme som følger av kulturell ekskludering, rasisme, misogyni eller $\varnothing$ konomisk skeivfordeling. ${ }^{78}$ Slike følelser har den moralske

\footnotetext{
75 Jason Stanley, How Propaganda Works. Princeton og Oxford: Princeton University Press 2016.

${ }^{76}$ Eric Fassin, Populism Left and Right. Prickly Paradigm Press 2019; Jean L. Cohen, «Populism and the Politics of Resentment», i Jus Cogens 1, nr. 5, 2019.

${ }^{77}$ Axel Honneth, Kamp om anerkjennelse. Om de sosiale konfliktenes moralske grammatikk. Oslo: Pax forlag 2008.

${ }^{78}$ Mouffe, For a Left Populism, 6.
} 
indignasjonen til felles med den sterke pathos, men de trenger verken hat eller frykt for å motivere til politisk handling.

\section{Konklusjon}

Er populistisk retorikk bra eller dårlig for det deliberative demokratiet? De som først og fremst forbinder begrepet «populisme» med «fake news», Donald Trumps bølleretorikk, demonisering av pressen, muslimhat og klimafornektelse, vil ikke overraskende svare det siste. Min diskusjon har likevel vist at saken er mer komplisert enn som så. Jeg definerte populisme bredt som en retorisk appell til motsetningen mellom «folket»og «makthaverne» (ev. «eliten» eller «systemet») og hevdet videre at vi kan skille mellom sterke og svake varianter av denne appellen. Sterk populisme er uforenlig med selve ideen om deliberativt demokrati, og har en rekke skadelige konsekvenser for de tre deliberative funksjonene: den demokratiske, epistemiske og etiske. De svake variantene, derimot, appellerer også til en motsetning mellom «folket» og «makthaverne», men på en måte som er prinsipielt forenlig med deliberativt demokrati. På tross av at svak populisme altså ikke står i direkte motstrid med det deliberative demokratiidealet, viste jeg likevel hvordan den både kan ha negative og positive konsekvenser for de tre deliberative funksjonene: den demokratiske, den episteiske og den etiske.

En fordel med min modell er, som vi har sett, at den tillater oss å betrakte «populisme» som en graduell betegnelse, både i den forstand at populisme kan være enten svak eller sterk, og i den forstand at en politisk aktør kan anvende populistisk retorikk i større eller mindre grad, for eksempel ved å veksle mellom populistisk og ikke-populistisk retorikk, eller ved å veksle mellom den svake og den sterke varianten. Dette gir for det første et mer realistisk bilde av hvordan populisme faktisk kommer til uttrykk i realpolitikken: Det er ingen politikere eller partier som alltid anvender en populistisk retorikk, eller som aldri anvender det. For det andre gjør mitt skille mellom svak og sterk populisme at jeg kan gå i dialog både med den delen av populismeforskningen som ser populisme som et langt på vei positivt fenomen, dvs. et slags demokratisk korrektiv eller folkelig oppgjør med bestående maktforhold (denne er mest opptatt av venstrepopulisme), og med den delen som definerer populisme som en trussel mot det liberale demokratiet (denne er mest opptatt av høyrepopulisme). 
Når min modell går i dialog med disse to tendensene i populismeforskningen, unngår den to problematiske former for polarisering. Den første formen er den som ligger i Laclau og Mouffes oppvurdering av populismens «oss mot dem»-logikk. Som jeg har påpekt, utgjør denne logikken et problem for den Laclau-inspirerte venstrepopulismen (for eksempel den vi finner hos Mouffe), fordi den innebærer en mer eller mindre eksplisitt påstand om at de som ikke deler venstrepopulismens prosjekt, ikke er legitime medlemmer av «folket».

Den andre formen er knyttet til Muddes ideologiske definisjon, der populisme ikke er en graduell betegnelse, men en beskrivelse av politiske aktørers faktiske (og problematiske) antakelser og holdninger. Fordi denne definisjonen innebærer en enten/eller-logikk, bekrefter den også det kategoriske skille mellom «populistene»og «ikke-populistene». I en tid der beskyldninger om populisme i den politiske offentligheten sitter løst, er dette lite fruktbart, fordi det reproduserer en antagonisme som oftest er mer ideologisk enn reell, nemlig den mellom «de gode demokrater» (ikke-populistene) og «det liberale demokratiets fiender»(populistene). Min retoriske tilnærming forholder seg derimot til spesifikke ytringer, fremsatt av spesifikke aktører, og klassifiserer dem som mer eller mindre populistiske. Den antar dermed ikke at populister generelt sett - eller «dypest sett»-ikke anerkjenner pluralisme og demokratisk opposisjon. Den er dermed bedre egnet til å gå i dialog med populistiske aktører og deres tilhengere: Den er ikke ukritisk, men den baserer sin kritikk på noe som faktisk blir hevdet, ikke på en generaliserende påstand om populistens «mentale ramme». 